\title{
The Impact of Trade and Debt on Nigeria Agribusiness Sector Output (1970-2010)
}

\author{
Dr. Okwudili Beede Emerole, Onwusiribe Ndubuisi C, Ngige Chigbo. D(Ph.D) \\ Department of Human Resource Management, College of Management Sciences Michael Okpara University of \\ Agriculture, Umudike Umuahia Abia State, Nigeria. \\ Department of Agribusiness and Entrepreneurship Management College of Management Sciences Michael \\ Okpara University of Agriculture, Umudike, Abia State, Nigeria \\ Department of Business Administration Anambara state University Igbariam Campus, Nigeria
}

\begin{abstract}
This paper analyzed the impact of trade and debt on Nigeria agribusiness sector output from 19702010. Trend analysis was used to examine the trend of agribusiness sector output, trade and debt. The study employed OLS estimates and found that import, external debt and domestic debt had influence on the agribusiness output but the OLS estimates was not the blue-best linear unbiased estimator, hence the need for unit root analysis on the series. It was found that the series was stationary at second difference using the Augmented Dickey-Fuller Test, with three cointegrating equations existing among the linear combinations using Johansen's Multivariate Cointegration Test. The error correction estimates indicates that the variables had no short run and long run relationship between the Agribusiness sector output except for external debt that had a long run relationship. Overall, external debt, domestic debt and export accounted for 70.4, 97.2, 85.9 and 74.9 percent of the variation in agribusiness sector output. Based on the findings it is recommended policy maker should adequately consider the variables as they were found to have influence on the agribusiness sector.
\end{abstract}

Keywords: impact, trade, debt, agribusiness, output

\section{Introduction}

Most developing economies in Africa trade on the raw material either agricultural products or mineral resource and they have a high profile of debt both domestically and externally, the issue of trade and borrowing (debt) are very vital issues affecting the economy of most nations especially a developing economy like Nigeria. Trade is the major engine to economic development both at the micro and macro level (Afaha \& Aiyelabola, 2012). Foreign trade is the exchange of capital goods and services between countries, it allows a nations to expand her market for both good and services, that are either in surplus or deficit in its economy. The country sells it surplus goods (goods and services it has a comparative advantage) to other countries that need them and buy the good and services it is comparatively disadvantaged (Adewuyi, 2000). Before 1972, most of Nigerian exports were agricultural commodities like cocoa, palm produces, cotton and groundnut. Thereafter, minerals, especially petroleum, became significant export commodities. By 1960, imports were valued at N432million. They increased to N758.99million and N8.132million in 1970 and 1978 respectively, rising to N124, 162.7million in 1 and N681, 728.3million in 1987. Food import became noticeable in Nigeria foreign trade. The country had an unfavorable trade balance from 1960 to 1965, partly because of the aggressive drive to import all kinds of machinery to stimulate the industrialization strategy pursued immediately after independence. Thereafter, export of crude petroleum guaranteed a favorable trade balance. The oil sector dominates export while the agribusiness sector dominates import (Afaha \& Aiyelabola, 2012)[2].

In modern law, debt has no precisely fixed meaning and may be regarded essentially as that which one person legally own to another or an obligation that is enforceable by legal action to make payment of money. Soludo (2003)[15], stated that countries borrow for two broad categories, macro-economics reason (higher investment higher consumption i.e. education and health or to finance transitory balance of payment deficit to lower nominal interest rates abroad lack of domestic long term credit or to circumvent hand budget constraint. Thus that economy indulges in debt to boost economic growth and reduce poverty and do not suffer from macro-economic instability polices that distort economic incentive or sizeable adverse shocks. As a result of this, growth is likely to increase and allow for timely debt payment. When the circle is maintained for a period of time growth will affect per capita positively which is a prerequisite for poverty reduction. The predictions are known to hold even in theories base on the more realistic assumption that countries may not be able to borrow freely because of the risk of debt denial.

In Nigeria, agribusiness has been one the most important single activity in the nation's economy, with about $70 \%$ of the total working population engaged in it (Oji-okoro, 2011)[12]. It accounts for the largest proportion of total labour employment and as a vital source of foreign exchange in its export orientation. Agricultural export remains one major source of foreign earning aside the oil sector and has played a prominent 
role in supporting capital development projects. In Nigeria, economic growth has largely been accounted for by resilient agricultural growth. According to the Nigeria Vision 2020 First Implementation Plan for the period 2010-2013, the agricultural sector contributed 73\% of GDP growth over the period 1999-2009. With real growth averaging about $7 \%$ per annum from 2004-2008, and value added to the tune of $42 \%$ of the Gross Domestic Product (GDP) within the same period, the agricultural sector in Nigeria clearly stands out as the most dominant and leading component of economic growth (Eboh et al,2012)[8]. The economy, comprising two broad output groups of oil and non-oil sectors, witnessed slower growth output in the third quarter of 2012 as a result of declines in non-oil sector output. While the oil sector witnessed positive growth for the first time in four quarters, the slower non-oil sector growth was driven by growth in activities recorded in the building and construction, cement, hotel and restaurant, as well as the Agribusiness sectors.

Nigerian agribusiness enterprises include the whole gamut of operations in the agricultural production, processing, distribution, and consumption spectrum. Agribusiness enterprises in Nigeria are classified into four major groups, farming input supply companies, producing farm firms, food processing agribusiness firms, and food marketing and distribution agribusiness organizations. These four groups can be found in the formal and informal sector of the economy. Agribusiness firms are scattered all over the country but are concentrated in three main industrial clusters in Nigeria; Kano Kaduna Jos in the north; Lagos-Otta-Ibadan in the south west and Port Harcourt-Aba-Nnewi- Onitsha in the southeast. In general, the Lagos-Otta-Ibadan axis accounts for 44 percent of the registered firms and roughly 52 percent of the employment. Based on the average number of employees per firm, the largest firms are also located in the Lagos area. While most of the sector is made up of small-scale enterprises (about 60 percent of the firms have between 20 and 49 employees), these only account for 12 percent of employment. With a few exceptions, firms with more than 500 employees provide the bulk of sectoral employment and account for 53 percent of total employment. Ajayi (1989)[3] traces the origin of Nigeria's debt problems to the collapse of the international oil price in 1981 and the persistent suffering of the international oil market and partly due to domestic lapses. As a result of the debt problem, credit facilities gradually dried up, which led to a number of project getting stalled (Odofu et al, 2010[11]; Asogwa, 2005)[6]. Ajayi (1989)[3] and Sanusi (1988)[14] advocated the revival of the economy growth as the best and most durable solution to the debt burden. The needed growth, however, is disturbed by two factors, which include, limitation imposed by inappropriate domestic policies and the external factors, which are beyond the control of the economy.

Alison et al (2003)[5] revealed the reasons for government borrowing as the fund from oil mineral and agricultural exports are not sufficient enough to finance budget deficit. The borrowing of Nigeria is mainly meant to carter for budget deficit and infrastructural development. Other factors that have contributed to the increasing debt level include high budget deficit, low output growth, large expenditure growth, high inflation rate and narrow revenue base of other sectors other than oil. The government borrowing comes in the form of external and domestic borrowing, the external borrowing involves the fund sourced outside the borders of the country while the internal borrowing include funds sourced within the borders of the country and this two make up the debt profile of an economy (Ajayi et al, 2012; Adebayo, 1990; Oyneiwu, 2012) [1] [4] [13]. Most of the debts incurred in Nigeria is meant to finance investment and capital intensive projects in the agribusiness sector of the economy. The economy of Nigeria is really dependent on the import of finished products and the exports of its raw products especially agricultural products (Oji-okoro, 2011)[12]. Despite the volume of trade going on in the Nigerian economy the balance of trade have recorded deficit for some years. The government borrowing is meant to enhance the productivity and output of the economy especially the agribusiness sector in order to achieve mechanization, industrialization and commercialization of the sector and improve its balance of trade. It is therefore important to study the impact of trade and debt on the agribusiness sector of Nigeria from 1970 to 2010. The specific objectives of this study is to analyze the trend in Agribusiness output of Nigeria, analyze the trend of agribusiness output and Nigeria trade, analyze the trend of agribusiness output and the Nigeria debt profile and examine the relationship between agribusiness sector output, trade and debt profile of Nigeria.

\section{Methodology}

This study uses principally secondary data obtained from the central bank of Nigeria and Bureau of Statistics for a period between 1970 - 2010. In the analyses of the trend in Agribusiness sector, trade and debt descriptive statistics such as graph was employed. The paper adopts econometric approach to test the degree of correlation between the variables by employing the multiple regression analysis of the Ordinary Lease Square (OLS) method. Other error correction models employed because of the high value of the R2 and the F-statistics of the OLS regression which indicates the presence of errors and the regression may not be the estimator. The error correction models employed include the Vector Error correction estimates, the Unit Root Test using the Augmented Dickey-Fuller technique to test if the time series data is stationary, the Johansen's Co-integration Test which shows the short run and long run relationship between the specified variables and the Vector Error Correction Estimates. This regression technique was employed to test the hypothesis (HO) there is no functional 
relationship between Agribusiness output, export, imports, domestic debt and external debt. The model is specified implicitly below:

OUT $=\mathrm{f}($ EXP ,IMP,DMD,EXD,Z) (1)

Where $\mathrm{Z}$ contains other variables not explicitly included in the model.

The explicit form of equation (1) above is represented as follows:

$\mathrm{OUT}=\alpha 0+\alpha 1 \mathrm{EXP}+\alpha 2 \mathrm{IMP}+\alpha 3 \mathrm{DMD}+\alpha 4 \mathrm{EXD}+\mu(2)$

Where:

OUT: agribusiness sector output

EXP: exports

IMP: imports

DMD: domestic debt

EXD: external debt

$\mu$ : error term controlling for unit-specific residual in the model

$\alpha 0$ : intercept of the regression line

\section{Result and Discussion}

\subsection{The trend in Agribusiness sector output of Nigeria (1970-2010)}

Chart 1 represents the trend analysis plots of Agribusiness output from 1970-2010. The dotted nodes represent the actual trend of the agribusiness output, the square nodes represent the fit line and the dotted faint nodes represent the forecast. From the year 1970-1980 the agribusiness sector output maintained a stable trend with a slight increase in the year 1975. The year 1981 experienced a sharp increase which continued until the 2010 which experienced a slight decrease. The ten years forecast from 2010 to 2020 indicates that the agribusiness output is estimated to experience growth in the next ten years. The line of fit indicates that the agribusiness output is experiencing a linear increase.

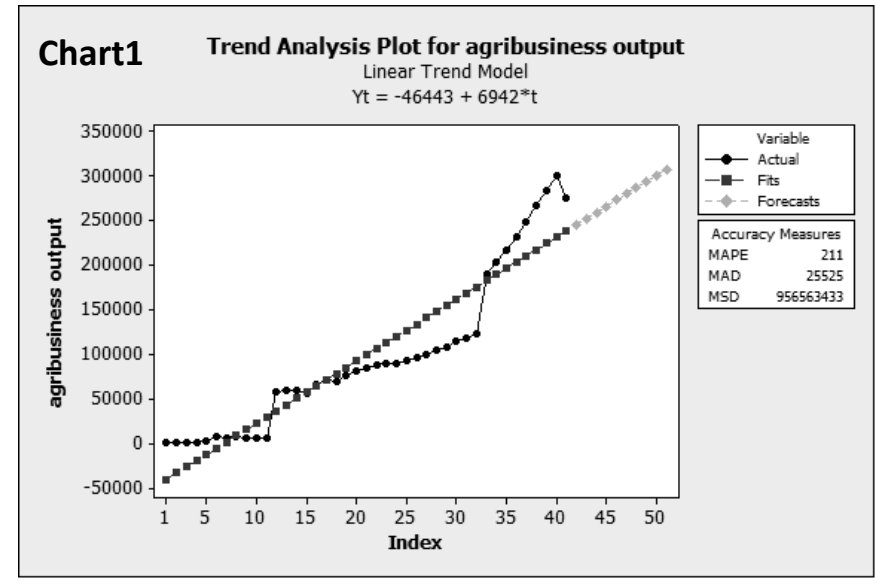

Source: computed from CBN statistical bulletin various issues.

\subsection{The trend of Agribusiness sector out, export and import}

From chart 2 below the shows the trend in agribusiness sector output and the Nigeria export. The chart indicates that the Agribusiness output has have been very low compared to amount of export from the economy. This is due to the current situation of the Nigerian exports, dominated by crude oil exports. The output of the agribusiness sector had less contribution to the export of the economy. From the year 2000 the economy experienced a sharp rise in its export while the agribusiness sector output remained on the low level.

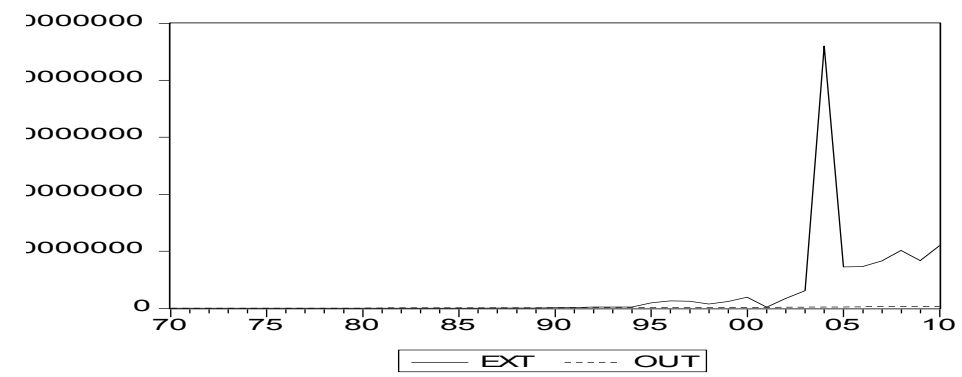

Chart 2: trend of agribusiness sector output and the Nigeria export

Source: computed from CBN statistical bulletin various issues. 
Chart 3 shows the trend of agribusiness sector output and the Nigerian imports. The agribusiness sector output of Nigeria was very low compared to the countries importation. From 1990-2010 the countries imports remained on the increase while the agribusiness sector output remained on the low side despite the agrarian nature of the people of Nigeria.

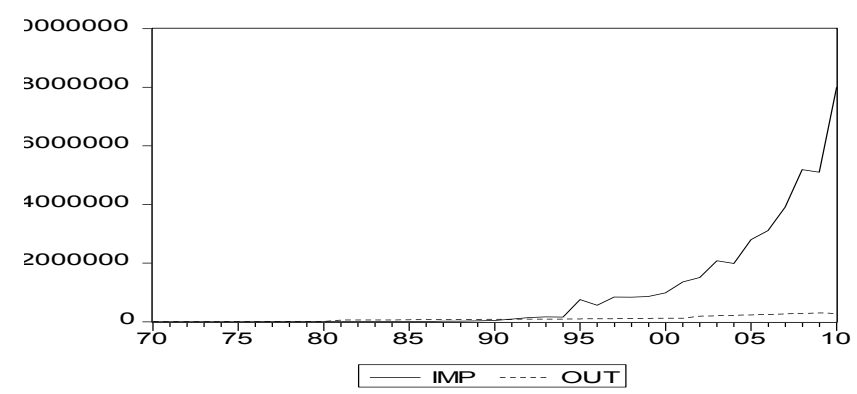

Chart 3: trend of agribusiness sector output and Nigeria Import.

Source: computed from CBN statistical bulletin various issues.

\subsection{The trend of agribusiness sector output, domestic debt and external debt of Nigeria.}

Chart 4 shows the trend of agribusiness sector output and the external debt of Nigeria. The chart clearly indicates that despite the increase in the external debt of Nigeria, the agribusiness sector output of Nigeria remained very low. Nigeria has borrowed heavily to finance investment in the agricultural sector to encourage it commercialization and industrialization but little have been achieved (Azih, 2011)[7]. The external debt of the economy and the agribusiness sector output of the nation maintained a similar trend in the early 1980's before the external debt profile of the economy started increasing.

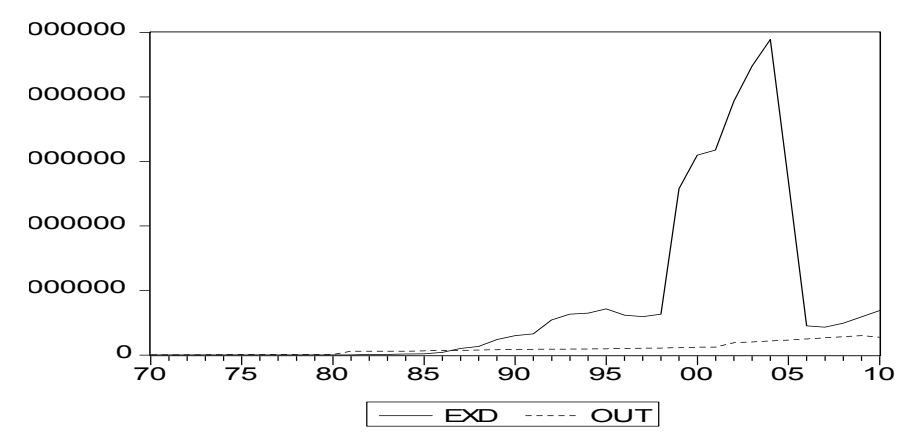

Chart 4: trend of agribusiness sector output and Nigeria external debt

Source: computed from CBN statistical bulletin various issues.

Chart 5 shows the trend of the Nigeria agribusiness sector output and the domestic debt. The domestic debt of Nigeria has experienced an increase from the late 1980's despite maintaining a relatively stable trend with the agribusiness sector output in the early 1980's. The agribusiness sector output have maintained a relatively low and stable trend in the early 1990's while the domestic debt increased sharply in 1999 before experiencing a decrease in 2005

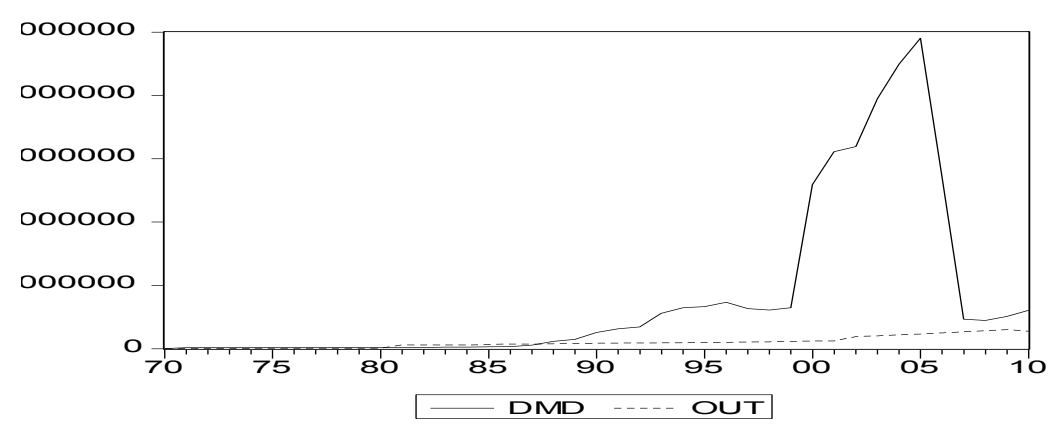

Chart 5: trend of agribusiness sector output and Nigeria external debt

Source: computed from CBN statistical bulletin various issues. 
3.4. The relationship between Agribusiness sector output, import, export, domestic debt and external debt.

We employ econometric method of data analysis in order to explore the relationship between Agribusiness output, import, export, domestic debt and external debt from 1970-2010.

\section{OLS regression estimates}

The OLS regression estimate in table 1 with the coefficient of multiple determination (R2) with the value of 0.862 indicates that the total variation in the Agribusiness sector output was accounted for by the independent variables included in the model. The F-test statistics value of 56.075 indicates that the model is statistically significant at 1 percent.

External debt was significant at 1percent and positively related to Agribusiness sector output indicating that an increase in the external borrowing of Nigeria to finance projects and investment especially in the agribusiness sector will increase the output of the sector. Domestic debt was significant at 5 percent and positively related to agribusiness sector output of the economy. This implies that an increase in access to fund especially by agribusiness enterprises will boost the output of agribusiness sector. Imports was significant at 10 percent and positively related to agribusiness sector output.

From the result of the estimated OLS regression equation, F-statistics of 56.075 were far too high. Since the estimation was not a blue-best linear unbiased estimator, there is an implication that the result may be unreliable as the time series may not be stationary. Hence, the need for a unit root test.

Table 1OLS Estimate

\begin{tabular}{|c|c|c|c|c|}
\hline Variable & Parameter & S.E. & T-STAT & $\mathrm{p}$-value \\
\hline $\operatorname{exd}[\mathrm{t}]$ & 0.016733 & 0.004882 & $3.427302 * * *$ & 0.00077 \\
\hline $\mathrm{dmd}[\mathrm{t}]$ & 0.039765 & 0.016121 & $2.466688 * *$ & 0.009265 \\
\hline imp[t] & 0.015039 & 0.010412 & $1.444384 *$ & 0.078639 \\
\hline $\exp [t]$ & 0.000416 & 0.000932 & 0.44667 & 0.328894 \\
\hline $\begin{array}{l}\text { Constant } \\
\text { Multiple } \\
\mathrm{R}\end{array}$ & $\begin{array}{r}42274.17091 \\
0.928277\end{array}$ & 6890.103035 & $6.135492 * * *$ & 0 \\
\hline $\begin{array}{l}\text { R-squared } \\
\text { Adjusted } \\
\text { R-squared }\end{array}$ & $\begin{array}{l}0.861698 \\
0.846331\end{array}$ & & & \\
\hline \multicolumn{5}{|c|}{$\begin{array}{l}\text { Multiple Linear } \\
\text { Regression - Residual } \\
\text { Statistics }\end{array}$} \\
\hline Standard E & & 34835.31381 & & \\
\hline Sum Squar & Errors & 43685967187 & & \\
\hline Log Likelih & & -484.304254 & & \\
\hline Durbin-Wa & & 0.744731 & & \\
\hline
\end{tabular}

Source: computed from CBN statistical bulletin various issues

*** statistically significant at 1 percent, ${ }^{* *}$ statistically significant at 5 percent *statistically significant at 10 percent

\section{Unit Root Test}

Most time series data are not stationary at levels. This implies that most Ordinary Least Square (OLS) regression that are carried out at levels may not be reliable. Based on this testing for stationary of variable to obtain a more reliable result become a necessity. The Augmented Dickey-Fuller root test was employed at first difference and second difference from table 2 it was evident that all the variable were stationary at second difference and thus the need for cointegration test. 
The Impact Of Trade And Debt On Nigeria Agribusiness Sector Output (1970-2010)

\begin{tabular}{|c|c|c|c|c|c|c|}
\hline \multirow[b]{2}{*}{ Variable } & \multirow{2}{*}{$\begin{array}{l}\text { First difference } \\
\text { Coefficient }\end{array}$} & \multicolumn{5}{|c|}{ Second difference } \\
\hline & & $\begin{array}{l}\text { Standard } \\
\text { error }\end{array}$ & ADF stat & Coefficient & $\begin{array}{l}\text { Standard } \\
\text { error }\end{array}$ & ADF stat \\
\hline EXD & -0.779857 & 0.178350 & -4.372614 & -1.538264 & 0.234110 & -6.570693 \\
\hline DMD & -1.977659 & 0.280429 & -7.052260 & -3.074542 & 0.266195 & -11.54997 \\
\hline IMP & 0.130036 & 0.257845 & 0.504318 & -3.985989 & 0.356569 & -11.17872 \\
\hline EXT & -1.941399 & 0.276753 & -7.014907 & -2.430661 & 0.277059 & -8.773095 \\
\hline OUT & -0.934056 & 0.242334 & -3.854415 & -1.971152 & 0.304636 & -6.470525 \\
\hline \multicolumn{7}{|c|}{ Critical value } \\
\hline $1 \% * * *$ & & & & & & \\
\hline $5 \% \quad * *$ & & & & & & \\
\hline $10 \% \quad *$ & & & & & & \\
\hline
\end{tabular}

Source: computed from CBN statistical bulletin various issues

\section{Cointegration Tests}

When linear combinations of variables are stationary, then co integration becomes necessary. This implies that a long-run relationship may exist among them, which connotes that they may be disparity among them in the short run but in the long there will be unity among them. To establish whether long run relationship exist among the variables or not, cointegration test Johansen's multivariate method was carried out and reported in table 3 below. Using the likelihood ratio, the results points out that the null hypothesis of no cointegration among the variables are rejected in favour of the alternative hypothesis with three cointegrating equations at $5 \%$ level of significance because the values exceed the critical values. This indicates that there are at least two cointegrating equations, which implies that a unique long run relationship exist among the variable and the coefficient of estimated regression can be taken as equilibrium values.

Table 3 Johansen's Multivariate Cointegration Test

\begin{tabular}{|c|c|c|c|c|}
\hline Eigenvalue & $\begin{array}{l}\text { Likelihood } \\
\text { Ratio }\end{array}$ & $\begin{array}{c}5 \text { Percent } \\
\text { Critical Value }\end{array}$ & $\begin{array}{c}1 \text { Percent } \\
\text { Critical Value }\end{array}$ & $\begin{array}{l}\text { Hypothesized } \\
\text { No. of CE(s) }\end{array}$ \\
\hline 0.957528 & 235.4791 & 68.52 & 76.07 & None ** \\
\hline 0.766370 & 112.2812 & 47.21 & 54.46 & At most $1 * *$ \\
\hline 0.678853 & 55.57449 & 29.68 & 35.65 & At most $2 * *$ \\
\hline 0.241727 & 11.27611 & 15.41 & 20.04 & At most 3 \\
\hline 0.012342 & 0.484323 & 3.76 & 6.65 & At most 4 \\
\hline
\end{tabular}

\section{Vector error correction model}

Table 4 presents the short run component of the estimated vector error correction model (VECM), with the restriction implied by the two CES's imposed. Examination of the F-statistics and adjusted $\mathrm{R}^{2}$ suggest that the variables in VECM significantly explained the short run changes in the EXD, DMD, IMP, and EXT at $\mathrm{p}<0.05$, accounting for $70.4,97.2,85.9$ and 74.9 percent of the variation in the four series respectively, but not for OUT. But while the cointegrating error correction coefficients in the EXD was statistically significant at 1 percent with a negative sign, DMD was statistically significant at 1percent with a positive sign and EXT was statistically significant at 1 percent and with a negative sign, but OUT and IMP was not statistically significant even at 10 percent. This shows that EXD, DMD and EXT in Nigeria, adjusts significantly to shocks to its equilibrium with its hypothesized determinants, that are caused by the exogenous changes in the variables past values but IMP and OUT do not. Effect on OUT of shocks that destabilizes the equilibrium relationship between OUT and the variable are corrected within 0.240 ( 88 days).

Focusing on the long term coefficient (elasticities) shows that on the long run EXD, have a significant influence on output with a positive sign. This implies that an increase in external debt for investment in the Agribusiness sector will lead to increased output of the sector. However, virtually all the hypothesized determinants had no significant influence on the Agribusiness sector output(OUT) except for EXD in the long run. 


\begin{tabular}{|c|c|c|c|c|c|}
\hline Error Correction: & $\mathrm{D}(\mathrm{EXD})$ & $\mathrm{D}(\mathrm{DMD})$ & D(IMP) & $\mathrm{D}(\mathrm{EXT})$ & $\mathrm{D}(\mathrm{OUT})$ \\
\hline CointEq1 & $\begin{array}{c}-0.032995 \\
(0.00819) \\
(-4.02725)\end{array}$ & $\begin{array}{l}0.029293 \\
(0.00193) \\
(15.1648)\end{array}$ & $\begin{array}{r}-0.000162 \\
(0.00478) \\
(-0.03396)\end{array}$ & $\begin{array}{r}-0.401553 \\
(0.11286) \\
(-3.55808)\end{array}$ & $\begin{array}{c}8.59 \mathrm{E}-05 \\
(0.00036) \\
(0.24014)\end{array}$ \\
\hline $\mathrm{D}(\operatorname{EXD}(-1))$ & $\begin{array}{l}0.189139 \\
(0.17622) \\
(1.07331)\end{array}$ & $\begin{array}{l}0.099441 \\
(0.04155) \\
(2.39345)\end{array}$ & $\begin{array}{l}0.108082 \\
(0.10281) \\
(1.05128)\end{array}$ & $\begin{array}{r}-0.542501 \\
(2.42742) \\
(-0.22349)\end{array}$ & $\begin{array}{r}-0.003175 \\
(0.00770) \\
(-0.41251)\end{array}$ \\
\hline $\mathrm{D}(\operatorname{EXD}(-2))$ & $\begin{array}{l}0.173103 \\
(0.15592) \\
(1.11023)\end{array}$ & $\begin{array}{l}0.108246 \\
(0.03676) \\
(2.94467)\end{array}$ & $\begin{array}{r}-0.011749 \\
(0.09096) \\
(-0.12916)\end{array}$ & $\begin{array}{l}3.497370 \\
(2.14773) \\
(1.62840)\end{array}$ & $\begin{array}{l}0.008167 \\
(0.00681) \\
(1.19929)\end{array}$ \\
\hline $\mathrm{D}(\mathrm{DMD}(-1))$ & $\begin{array}{l}1.510030 \\
(0.44287) \\
(3.40965)\end{array}$ & $\begin{array}{r}-1.885877 \\
(0.10442) \\
(-18.0613)\end{array}$ & $\begin{array}{l}0.645056 \\
(0.25838) \\
(2.49657)\end{array}$ & $\begin{array}{l}20.15191 \\
(6.10050) \\
(3.30332)\end{array}$ & $\begin{array}{l}0.004278 \\
(0.01934) \\
(0.22119)\end{array}$ \\
\hline $\mathrm{D}(\mathrm{DMD}(-2))$ & $\begin{array}{l}1.140557 \\
(0.34609) \\
(3.29559)\end{array}$ & $\begin{array}{r}-1.479432 \\
(0.08160) \\
(-18.1311)\end{array}$ & $\begin{array}{r}-0.295371 \\
(0.20191) \\
(-1.46287)\end{array}$ & $\begin{array}{l}8.659352 \\
(4.76730) \\
(1.81640)\end{array}$ & $\begin{array}{l}0.009499 \\
(0.01512) \\
(0.62840)\end{array}$ \\
\hline D(IMP(-1)) & $\begin{array}{r}-0.537792 \\
(0.37311) \\
(-1.44136)\end{array}$ & $\begin{array}{l}0.561897 \\
(0.08797) \\
(6.38745)\end{array}$ & $\begin{array}{l}0.260364 \\
(0.21768) \\
(1.19609)\end{array}$ & $\begin{array}{l}2.710390 \\
(5.13962) \\
(0.52735)\end{array}$ & $\begin{array}{l}0.017199 \\
(0.01630) \\
(1.05542)\end{array}$ \\
\hline $\mathrm{D}(\operatorname{IMP}(-2))$ & $\begin{array}{l}0.673025 \\
(0.30056) \\
(2.23925)\end{array}$ & $\begin{array}{l}0.252089 \\
(0.07086) \\
(3.55745)\end{array}$ & $\begin{array}{l}1.291893 \\
(0.17535) \\
(7.36752)\end{array}$ & $\begin{array}{r}-1.111351 \\
(4.14016) \\
(-0.26843)\end{array}$ & $\begin{array}{r}-0.005107 \\
(0.01313) \\
(-0.38905)\end{array}$ \\
\hline $\mathrm{D}(\mathrm{EXT}(-1))$ & $\begin{array}{l}0.053022 \\
(0.02861) \\
(1.85356)\end{array}$ & $\begin{array}{r}-0.106401 \\
(0.00674) \\
(-15.7764)\end{array}$ & $\begin{array}{l}0.005462 \\
(0.01669) \\
(0.32726)\end{array}$ & $\begin{array}{l}0.489362 \\
(0.39404) \\
(1.24191)\end{array}$ & $\begin{array}{r}-9.98 \mathrm{E}-05 \\
(0.00125) \\
(-0.07988)\end{array}$ \\
\hline $\mathrm{D}(\mathrm{EXT}(-2))$ & $\begin{array}{l}0.006722 \\
(0.01660) \\
(0.40505)\end{array}$ & $\begin{array}{r}-0.068080 \\
(0.00391) \\
(-17.4001)\end{array}$ & $\begin{array}{l}0.017077 \\
(0.00968) \\
(1.76379)\end{array}$ & $\begin{array}{l}0.157380 \\
(0.22860) \\
(0.68846)\end{array}$ & $\begin{array}{r}-0.000366 \\
(0.00072) \\
(-0.50528)\end{array}$ \\
\hline D(OUT(-1)) & $\begin{array}{l}0.228602 \\
(4.60491) \\
(0.04964)\end{array}$ & $\begin{array}{l}0.533171 \\
(1.08570) \\
(0.49109)\end{array}$ & $\begin{array}{r}-0.323044 \\
(2.68657) \\
(-0.12024)\end{array}$ & $\begin{array}{l}30.73750 \\
(63.4324) \\
(0.48457)\end{array}$ & $\begin{array}{l}0.018237 \\
(0.20112) \\
(0.09068)\end{array}$ \\
\hline $\mathrm{D}(\mathrm{OUT}(-2))$ & $\begin{array}{r}-1.394869 \\
(4.83995) \\
(-0.28820)\end{array}$ & $\begin{array}{l}1.618380 \\
(1.14111) \\
(1.41825)\end{array}$ & $\begin{array}{r}-4.548050 \\
(2.82370) \\
(-1.61067)\end{array}$ & $\begin{array}{l}325.5127 \\
(66.6699) \\
(4.88245)\end{array}$ & $\begin{array}{r}-0.154164 \\
(0.21139) \\
(-0.72929)\end{array}$ \\
\hline $\mathrm{C}$ & $\begin{array}{r}-209104.8 \\
(97427.4) \\
(-2.14626) \\
\end{array}$ & $\begin{array}{l}282326.6 \\
(22970.4) \\
(12.2909) \\
\end{array}$ & $\begin{array}{r}-8397.292 \\
(56840.6) \\
(-0.14773)\end{array}$ & $\begin{array}{c}-4993368 \\
(1342056) \\
(-3.72069)\end{array}$ & $\begin{array}{l}5684.229 \\
(4255.25) \\
(1.33582)\end{array}$ \\
\hline R-squared & 0.792255 & 0.980512 & 0.901143 & 0.823849 & 0.260538 \\
\hline Adj. R-squared & 0.704363 & 0.972267 & 0.859319 & 0.749324 & -0.052311 \\
\hline Sum sq. resids & $3.13 \mathrm{E}+12$ & $1.74 \mathrm{E}+11$ & $1.06 \mathrm{E}+12$ & $5.93 E+14$ & $5.97 \mathrm{E}+09$ \\
\hline S.E. equation & 346803.8 & 81765.70 & 202330.3 & 4777198. & 15147.02 \\
\hline F-statistic & 9.013941 & 118.9241 & 21.54611 & 11.05463 & 0.832792 \\
\hline Log likelihood & -531.4569 & -476.5507 & -510.9803 & -631.1252 & -412.4806 \\
\hline Akaike AIC & 28.60300 & 25.71319 & 27.52528 & 33.84870 & 22.34109 \\
\hline Schwarz SC & 29.12013 & 26.23032 & 28.04241 & 34.36583 & 22.85822 \\
\hline Mean dependent & 18146.83 & 119758.8 & 210641.7 & 290377.9 & 7176.347 \\
\hline S.D. dependent & 637829.0 & 490992.8 & 539441.1 & 9541506. & 14765.74 \\
\hline
\end{tabular}

Source: computed from CBN statistical bulletin various issues.

\section{Conclusion}

From the trend analysis which shows that the agribusiness sector output of the economy assumes a linear progression based on the 5 years trend forecast. The trend of agribusiness sector output and trade and debt variable indicates that the outputs of the agribusiness sector is very low compared to import, export, external and domestic debt. The goal of this paper which is to examine the relationship between the agribusiness sector output and the selected debt and trade variables. Evidence from this study shows that the series of agribusiness sector output and its hypothesized determinants are generally stationary at second difference. This was necessary due to the OLS estimate was not the best estimator of the model though EXD, DMD, and IMP has influence on the agribusiness sector output. Johansen $(1992,1995)[9,10]$ system based co-integration test 
revealed that three co-integrating equations exist between the linear combination of the series. The error correction model indicates that none of the hypothesized determinants had influence on the agribusiness output in the short run and in the long run except for external debt which has influence on the agribusiness sector output in the long run. Based on the findings of this study it is very necessary to encourage a well-planned borrowing and importation as these have influence on the agribusiness sector output, since the agribusiness sector output has great potential of increase based on the trained forecast. External debt is found to have a long run influence on the output of the agribusiness sector and thus good policies and management should be considered.

\section{References}

[1] Adebayo (1990) Nigeria Exterbal Debt Crisis its Management. Malthouse Press Ltd. Lagos. Pg 23-27.

[2] Afaha, J and Aiyelabola, O. (2012). Foreign Trade and Economic Growth. Evidence from Nigeria. Arabia Journal of Business and Economic Research series No. 10 Ibadan Nigeria.

[3] Ajayi, E (1989) Nigeria Debt Management Experience. CBN of Nigeria Bullion April/June 1987 vol3 No 2 pg 25.

[4] Ajayi. L and Oke, M (2012) Effect of External Debt on Economic Growth and Development of Nigeria. International Journal of Business and Social Science Vol.3 no 12.

[5] Alison J (Eds) (2003) Key Issues for Analyzing Domestic Debt sustainability. Debt Relief International Publication. ISBN 1-903907-01.

[6] Asogwa, R.C. (2005). Domestic government debt structure, risk characteristics and monetary policy conduct, evidence from Nigeria. Access from: http://www.inf.org/external/np/res/seminars/2007/macro/pdf/asogwa.pdf

[7] Azih. I (2011). A Background Analysis of the Agricultural Sector (1998-2007). Oxfam Novib Economic Justice Campaign in Agricuture www.manufacturingtodynigeria.com.

[8] Eboh. E, Oduh. M and Ugah. O (2012). Drivers and Sustainability of Agricultural Growth in Nigeria. African Institute for Applied Economics AIAE Research paper 8.

[9] Johansen S (1992). Determination of Cointegration Rank in the Presence of a Linear Trend. Oxford Bull. Econ. Stat., 54: $383-397$.

[10] Johansen S (1995). Likelihood-based Inference in Cointegrated Vector Autoregressive Models. Oxford University Press, UK.

[11] Odofu. I and Abula. M (2010) Domestic Debt and the Nigerian Economy. Current Research Journal of Economic theory 2(1) 22-26.

[12] Oji-okoro. I (2011). Analysis of the Contribution of the Agricultural Sector on the Nigerian Economic Development. World Review of Business Research Vol.1.No 1. Pp191-200.

[13] Oyeiwu. C (2012) Domestic Debt and the Growth of Nigerian Economy. Research Journal of Finance and Accounting Vol 3, No 5,2012 .

[14] Sanusi, J (1988), Genesis of Nigerian debt problems and prospect of debt conversion; A Lecture delivered on Debt Conversion/ Asset Trading organized by Continental Merchant Bank of Nigeria Limited.

[15] Soludo. C (2003) "Debt poverty and Inequality" in Okonjo-Iweala, soludo and Mulitar (Eds) the Debt Trap in Nigeria, African World Press NJ pg 23-74. 